\title{
Marketing Strategy of Small and Medium Enterprises (MSMES) Through Instagram in the Marketing Era 4.0
}

\author{
Ni Komang Mela Tri Utari \\ Universitas Pendidikan Nasional, Denpasar Bali \\ melatriutari@gmail.com \\ Published: 17/03/2021 \\ How To Cite (In Apa Style): \\ Utari, Ni Komang Mela Tri. (2021). Marketing Strategy of Small and Medium Enterprises (MSMES) Through \\ Instagram in the Marketing Era 4.0. Jurnal Ekonomi Dan Bisnis Jagaditha, Vol. 8 (1), 15-22. Doi: \\ https://10.22225/jj.8.1.2772.15-22
}

\begin{abstract}
The purpose of this research is to understand and describe how the marketing strategy of MSMEs via Instagram in the Marketing 4.0 era. The data collection technique used was indepth interviews with the owner of Zeen Shake and its customers as many as 70 people. The selection of informants was carried out by a purposive sampling method and the data collected were analyzed using the Nvivo software version 12. The results of this study showed that Zeen Shake carried out a marketing strategy on Instagram by uploading photos and providing information in captions, providing promos on certain days, and also upload testimonials from consumers. Besides, researchers got new findings, namely Zeen Shake also markets its products through the mouth to mouth marketing or Word of Mouth Marketing (WOMM). In the current era of Marketing 4.0, a new customer path was found (New Customer Path), from 4A (Aware, Attitude, Ask, Act Again) to 5A (Aware, Appeal, Ask, Act, Advocate). This happens because of the use of technology which causes all people to connect with one another.
\end{abstract}

Keywords: Instagram, Marketing Strategy, New Customer Path, Word of Mouth Marketing

\section{INTRODUCTION}

In the era of Industrial Revolution 4.0, the mastery of technology is growing very rapidly. One of the most widely used technologies by the world community today to communicate and convey information is the internet. According to the Association of Indonesian Internet Service Providers (Asosiasi Penyelenggara Jasa Internet Indonesia (APJII), 2019) internet usage in 2018 as stated in Figure 1.

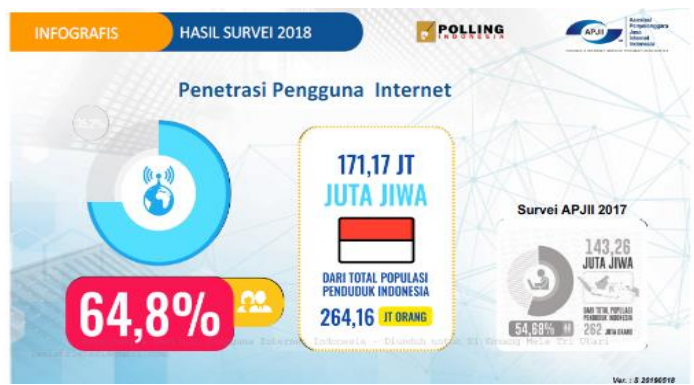

Figure 1. Penetration of Internet Use in 2018

In figure 1 it can be seen that in 2017 the percentage of Internet users was $54.68 \%$ and in 2018 increased by $64.8 \%$ in line with the increase in the population. These many internet users are a good potential for people who want to take advantage of one of them is the businessman.

Business people can see the opportunity to grow their business by marketing products through the internet. Digital marketing is one type of marketing that is widely used to promote products or services and to reach consumers using digital channels (Yasmin, Tasneem, \& Fatema, 2015). Digital marketing is a term for marketing products or services that use digital technology, especially on the internet, but also includes cell phones, display ads, and other digital media (Deekshith \& Kinslin, 2016).

Technological developments touch all industrial sectors therefore no industry can be immune to change (Kasali, 2017). Digital marketing will show you practically and efficiently how to harness the power of digital media and use it well in order to achieve maximum success in business both today, and in the future (Morris, 2009). Digital marketing communication has the same meaning as digital marketing as a means for entrepreneurs to market products and services sold through social media. 
In carrying out marketing communications, the company must have a strategy so that all company plans are achieved and also so that the company name can be known by many people. If a business let alone a new business that few people know, sometimes consumers still do not know it. Therefore, the company must market its products optimally such as marketing on social media.

Marketing 4.0 is a marketing approach that collaborates with online and offline interactions between companies and customers (Kartajaya, 2018). Although it is now called the era of the digital economy but digital interaction is not enough because the reality of offline is a point of strong differentiation. Marketing 4.0 also develops a machine to machine connectivity with artificial intelligence which is then balanced with human to human connectivity that will later strengthen customer engagement.

According to data from APJII in 2018 stated that the most visited social media content is Facebook at $50.7 \%$, then ranked second on Instagram at $17.8 \%$ and Youtube at $15.1 \%$ (Asosiasi Penyelenggara Jasa Internet Indonesia (APJII), 2019). The most popular social media is Instagram. In addition to entertainment, Instagram is also a business opportunity for owners of small businesses and businesses that already have big names

One of the drivers and economic strength of the Indonesian state is the presence of businesses, micro, small and medium enterprises (MSMEs). In addition to playing a role in economic drivers, MSMEs also absorb a lot of labor to reduce the unemployment rate. MSMEs were also able to stand firm during the crisis in 1997-1998. Since the era of reform, the new government realized the importance of MSMEs as an important supporter of the Indonesian economy and at that time many realized the importance of entrepreneurship, especially for young people as the successor of the nation's generation.

The culinary business is a promising business that is easy to find around us. Many people choose this business because food is a basic human need that must be met every day. Therefore, until whenever culinary business opportunities are always open to anyone and the profits are promising (SME Business, n.d.). Culinary business owners use Instagram to market their products because they are in line with the main target market of millennials who mostly have Instagram accounts.

Although researchers realize that sales promotion through the internet, especially Instagram social media is common and widely used by all circles, researchers feel that not all MSMEs use marketing strategies through Instagram social media appropriately. The process of forming a sales promotion strategy through social media is quite difficult because there are so many differences between consumers in Indonesia, namely how to shop, how to see sales promotions, economic conditions, and many other factors. This is what attracts researchers to discuss it further in scientific studies.

\section{CONCEPT \\ Marketing Strategy}

Marketing strategy is the main approach used by a business unit in achieving the goals set before which listed the main decisions regarding the target market, marketing mix, and the required level of cost of use (Kotler \& Keller, 2008). Marketing strategy is a fundamental tool planned to achieve the company's goal of developing competitive advantages used to serve a pre-targeted market (Sholihin, 2019).

\section{Dynamic Competitive Landscape}

Various marketing sciences can be applied but marketing is not a sure science and always develops along with the rapid development of technology. Kartajaya (2018) mentions that marketing does not start from the marketing mix but rather with the mastery of dynamic competitive landscape or dynamic competitive landscape consisting of 4C, namely Change consisting of technology, politics and law, economy, socio-cultural and market situation; Competitor; Customer; Company.

\section{Digital Marketing}

Digital marketing today is becoming a trend of society in the 4.0 era because the internet becomes part of daily human activities. Besides, the increasing use of the internet is also a factor that encourages the increase of digital marketing and the development of online businesses (Sholihin, 2019). Digital marketing campaigns are becoming more efficient as digital platforms are increasingly used in marketing plans and everyday life, and when people use digital devices instead of 
going to physical stores (Deekshith \& Kinslin, 2016).

\section{Marketing 4.0}

The concept of marketing continues to evolve from product-driven marketing (Marketing 1.0), then to customer-centric marketing (Marketing 2.0) next in humancentric marketing (Marketing 3.0) to finally now on a human to human marketing (Marketing 4.0). Kotler, Kartajaya, \& Setiawan (2019) introduced the concept of Marketing 4.0 which is a marketing approach that combines online and offline interactions with companies and customers. Also, Marketing 4.0 must pay attention to style and substance which means that a brand must be packaged following current trends (Kartajaya, 2018).

\section{New Customer Path 5C}

Kartajaya (2018) mentioned that the cause of the change in customer path from $4 \mathrm{~A}$ to $5 \mathrm{~A}$ is the technology that connects people with each other. This condition caused the customer path to change which used to consist of 4A (Aware, Attitude, Act and Act Again) which then changed to 5A (Aware, Appeal, Ask, Act, and Advocate). Attitude has been replaced by appeal and asks because people are now actively searching for information quickly and they will connect which causes them to distrust advertising. They prefer to find their information and ask their colleagues what they think about the products they are going to buy.

\section{Digital Marketing Utilization for MSMEs}

Digital marketing is currently being intensively used by businesses, one of which is promoting its products through social media. Digital marketing strategies affect up to $78 \%$ of the competitive advantages of MSMEs in marketing their products (Wardhana, 2015).

\section{CONCEPTUAL FRAMEWORK}

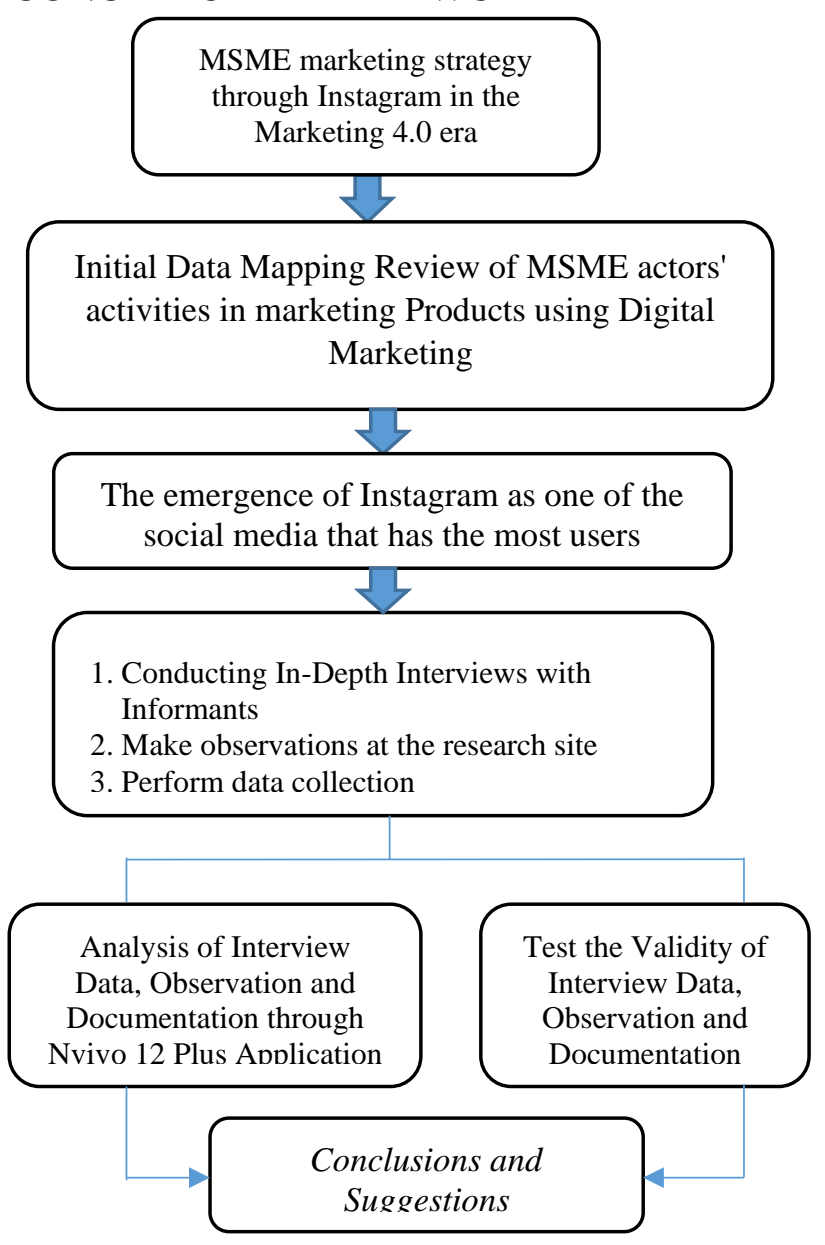

Figure 2

Conceptual Framework

\section{METHODS}

This research uses qualitative research that focuses on marketing strategies using Instagram on MSME actors in the culinary sector in the Marketing 4.0 era. The type of research used is phenomenology because the design of this study describes all participants when experiencing a similar phenomenon (Ghozali, 2013). The location chosen by the researchers as the research site is at Zeen Shake on Tegal Darmasaba Highway, Badung, Bali. The research time was conducted from September to December 2020. Researchers conducted in-depth interviews with informants namely business owner Zeen Shake and consumer Zeen Shake. The selection of informants is done by purposive sampling method where the selected informant meets the criteria of the researchers described as follows:

1. The informant is an active Instagram user 2.Informants with an age range of 17-30 years 
3. The informant knew Zeen Shake's location and had purchased the product.

4.Researchers will conduct an interview with business owner Zeen Shake

The target of the research informants found were consumers Zeen Shake as many as 5 people and informants who filled out questionnaires as many as 65 people so the total consumer informants were as many as 70 people.

The data analysis techniques used in this study used data analysis according to (Creswell, 2013) supported by the (Miles, Huberman, \& Saldana, 2014). Data analysis techniques in this study were assisted by Nvivo software version 12 plus.

\section{RESULT AND DISUCUSSION}

Marketing activities carried out by utilizing internet media can be done by everyone who has a business easily, quickly, and reaches a wide market that is unlimited space and time. Digital marketing is now a trend of society in the 4.0 era because the internet becomes part of daily human activities. Besides, the increasing use of the internet is also a factor that encourages the increase of digital marketing and the development of online businesses (Sholihin, 2019).

In marketing the product, Zeen Shake uses Instagram social media because social media is widely used by people, especially millennials. Zeen Shake implements three product marketing strategies on Instagram that can be described as follows:

1. Upload Foto And Product Information

To attract consumers' buying interest, Instagram account owners must create content as interesting as possible. Also, the account owner provides product information in the photos that have been uploaded to provide knowledge of the product to consumers through the feature on Instagram, namely in the photo caption.

2. Discounting Information

To attract consumers to shop, Zeen Shake provides discounts on certain days such as Galungan and Kuningan Holidays, Indonesian Independence Day, and other days.

3. Testimonials from consumers

Today's consumers tend to be selective before buying a product. They will find information for their friends or family first before purchasing a product. With testimonials from previous buyers, prospective consumers can be more confident and confident in the products sold by Zeen Shake that taste good, and the quality is guaranteed.

Marketing strategies by MSMEs in the culinary sector in the Marketing 4.0 era are very diverse. In addition to using Instagram, business owner Zeen Shake used a mouth-tomouth method especially at the beginning of the company's founding. Mouth to mouth marketing (WOMM) is an effort to provide information from one consumer through another. Marketing strategy through Word of Mouth (WOM) conducted by consumers about their experience in consuming products that unwittingly means informing the products they consume that can connotate free advertising for a company (Sari \& Dwiya, 2018).

Word of Mouth is influential with purchases and positively interconnected in the sense that consumers will communicate word of mouth and recommend to friends or family if the consumer is satisfied with the product that triggers consumers to make purchasing and repurchasing decisions (Molinari, Abratt, \& Dion, 2008). With respect to the purchasing decision process, the influence of word of mouth is very influential because Word of Mouth can be a powerful source of information in influencing purchasing decisions (Pratiwi \& Lubis, 2017).

The business world is currently experiencing a shift from what was once vertical to horizontal which caused the change in customer path from 4A (Aware, Attitude, Act and Act Again) to now changed to 5A (Aware, Appeal, Ask, Act, and Advocate) has been presented on the library review. This change in customer path comes from the internet phenomenon and gadgets that affect people's lives in the current era (Putri, 2019). At 5A, consumers are most at risk of influence in the ask (ask) and act (act) stages because at the questioning stage consumers will ask questions and ask for opinions from colleagues and absorb as much information as possible from outside influences. This questioning stage can be an opportunity for companies to make their product brands more preferred. While at the stage of acting, consumers will determine through their perception of the brand that they will buy without any outside pressure (Kotler et al., 2019). 
To process the data, researchers used Nvivo 12 Plus software to help compile existing data that can be seen in figure 5.1 below:

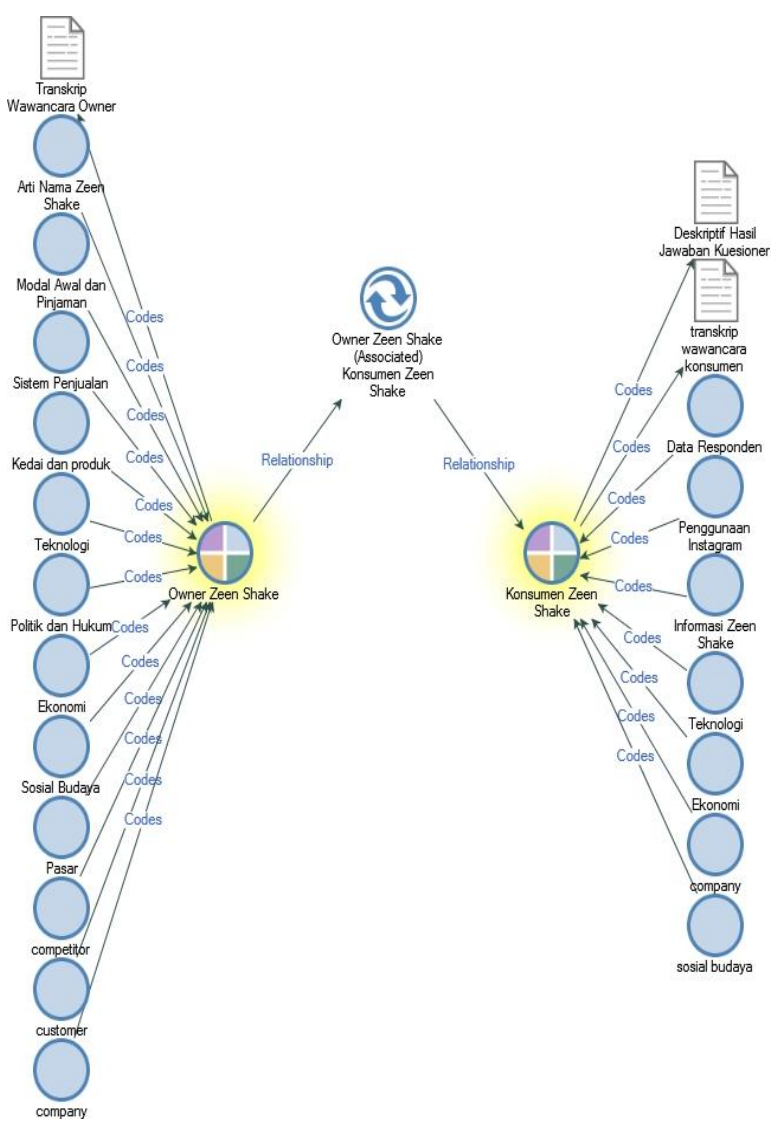

Figure 3

Diagram of Zeen Shake owner's relationship with consumers as seen from $4 \mathrm{C}$ business landscape analysis

From the diagram above can be seen that from the results of interviews, observations, and documentation with owners and consumers of Zeen Shake, there is a similarity of information between owners and consumers, namely seen from Change which includes Technology, Economics, and Social Culture and seen from the Company. As the owner of Zeen Shake is supposed to know in general about his company that can be seen in the picture above, namely The Meaning of Zeen Shake Name, Initial Capital and Loans, Sales System, Stores, and Products are included in the Company Overview.

After that go into $4 \mathrm{C}$ business landscape analysis starting from Change which includes Technology, Politics and Law, Economics, Socio-Cultural, and Market. Change is used to determine future threats and opportunities (Kartajaya, 2018). After that, there is a
Competitor or competitor that is a business competitor whose appearance can replace the company's products. For Zeen Shake, he sees competitors as a reference to continue to innovate and provide the best service for their consumers. Next, there is a customer or customer company Zeen Shake. Zeen Shake realizes that approach with consumers through good customer service is a key so that consumers can become regular customers.

Kartajaya (2018) said that companies must be careful in paying attention and analyzing changes in consumer behavior that can later be presented as key for companies to make decisions. And lastly, there is a Company or company in question here is not the strength of the company but its weaknesses first. According to (Kartajaya, 2018), if the company discusses the strength of the company first, it will tend to focus on what is positive about the company. In fact, the viability of the company is often determined by something that threatens the company in the future.

For consumer data, researchers have two sources, namely from interviews on consumer interview transcript files and from questionnaires from descriptive files of questionnaire answer results. Information about consumers, namely in Respondent Data, Instagram Usage, and Zeen Shake Information. In the 4C Business Landscape analysis, consumers have the same knowledge as the owner of Zeen Shake which is from Change which covers technology, economy, and socioculture. The technology in question is where the consumer knows Zeen Shake that is through social media Instagram. From the economy in question is the price of Zeen Shake products is affordable and the purchasing decision of one of the consumers affected by postage. After that, there is a socio-cultural consumer who knows Zeen Shake from his friend's recommendation and if they are satisfied with Zeen Shake products, they will recommend it to their friends or family. The second is that the Company referred to here is the criticism and advice from consumers Zeen Shake that can be used as input for the company to be better in the future.

So it can be seen that there is a similarity of information owned by the owner of Zeen Shake with its consumers and it relates to each other. For Zeen Shake owners, he knows more information about Zeen Shake as seen from 4C business landscape analysis namely change, 
competitor, customer, company. From the consumer side, they only know from change and company only because they see and know Zeen Shake from the outside of the service only. Therefore, their criticism and suggestions are needed by Zeen Shake so that the company can continue to answer consumer needs.

\section{CONCLUSION}

Based on the results of the research discussed in the previous chapter, it can be concluded as follows:

1. Zeen Shake's marketing strategy on Instagram is to first upload photos and product information, namely Zeen Shake as the owner of the Instagram account must upload photos of his company's products and provide information about the product in the caption Instagram. Both discount information, Zeen Shake will give discounts on certain days to attract consumers to shop more. The three testimonials from consumers are proof from Zeen Shake to consumers that the products sold taste good and the quality is guaranteed.

2. Mouth to mouth marketing (WOMM) conducted by Zeen Shake at the beginning of establishing a business. Word of mouth marketing is done because consumers believe more indirect recommendations from previous users than ads made by the company, therefore this marketing is also an option for companies in marketing their products. Zeen Shake consumers also participate in this marketing by recommending Zeen Shake to their friends or family if they are satisfied with the products sold by Zeen Shake.

3. In the era of the Industrial Revolution, 4.0 dominated by technology that caused all communities to connect through social media that caused the customer path that used to consist of 4A (Aware, Attitude, Ask, Act Again) is now changed to $5 \mathrm{~A}$ (Aware, Appeal, Ask, Act, Advocate). This change in customer path comes from the internet phenomenon and gadgets that affect people's lives in this era.

4. Researchers used Nvivo 12 Plus software to help process the data. From the results of the processing can be seen that there is a relationship between owners and consumers of Zeen Shake that they both have information about Zeen Shake as seen from the analysis of the business landscape 4C namely change, competitor, customer, company. For Zeen shake owners, he knows more information about Zeen Shake as seen from 4C business landscape analysis. From the consumer side, they only know from change and company only because they see and know Zeen Shake from the outside of the service only. Therefore, their criticism and suggestions are needed by Zeen Shake so that the company can continue to answer consumer needs.

\section{REFERENCES}

Asosiasi Penyelenggara Jasa Internet Indonesia (APJII). (2019). Penetrasi \& Profil Perilaku Pengguna Internet Indonesia Tahun 2018.

Creswell, J. W. (2013). Research Design, Qualitative, Quantitative, and Mixed Method Approaches (4th ed.). London: Sage.

Deekshith, D., \& Kinslin, D. (2016). A study on digital marketing and its impact. Journal of Chemical and Pharmaceutical Sciences, 9(4).

Ghozali, I. (2013). Desain Penelitian Kuantitatif dan Kualitatif. Semarang: Yoga Pratama.

Kartajaya, H. (2018). Citizen 4.0. Gramedia Pustaka Utama.

Kasali, R. (2017). Disruption. Jakarta: Gramedia.

Kotler, P., Kartajaya, H., \& Setiawan, I. (2019). Marketing 4.0: Moving from Traditional to Digital. In Asian Competitors, 99(123).

Kotler, P., \& Keller, K. L. (2008). Manajemen pemasaran (13th ed.). Jakarta: Erlangga.

Made Febri Purnama Sari, D., \& Gede Sri Dwiya, K. (2018). Strategi Digital Marketing, Word of Mouth (Wom), Service Quality Terhadap Keputusan Pemakaian Jasa Go-Jek. Journal Ilmiah Manajemen \& Bisnis, 3(2).

Miles, M. B., Huberman, A. M., \& Saldana, J. (2014). Qualitative Data Analysis: A Methods Sourcebook (III). Los Angeles: Sage Publication, Inc.

Molinari, L. K., Abratt, R., \& Dion, P. (2008). Satisfaction, quality and value and effects on repurchase and positive word-of-mouth behavioral intentions in a B2B services context. Journal of Services Marketing, 22(5).

Morris, N. (2009). Understanding Digital Marketing: Marketing Strategies for Engaging the Digital Generation. Journal of Direct, Data and Digital Marketing Practice, 10(4).

Pratiwi, Y. R., \& Lubis, E. E. (2017). Pengaruh Word of Mouth Communication terhadap Keputusan Pembelian pada Boardgame Lounge Smart Cafe Pekanbaru. Jurnal Online Mahasiswa Fakultas Ilmu Sosial Dan Ilmu Politik, 4(1). 
Putri, L. P. I. K. (2019). Perilaku Konsumen Pengguna Instagram di Era Marketing 4.0. Jurnal Manajemen Bisnis, 16(4).

Sholihin, R. (2019). Digital Marketing di era 4.0 (A. Ishartadi, Ed.). Yogyakarta: Quadrant.

Yasmin, A., Tasneem, S., \& Fatema, K. (2015). ffectiveness of Digital Marketing in the Challenging Age: An Empirical Study. The International Journal of Management Science and Business Administration, 1(5). 